ARTÍCULO ORIGINAL

\title{
Efecto de la persistencia bacteriana sobre la eficacia de la enrofloxacina y ciprofloxacina frente a una cepa de Escherichia coli
}

\author{
Patricelli P, Ramirez E, Presa Rossa C, Dell'Elce A, Formentini E*
}

Laboratorio de Farmacología y Toxicología - Facultad de Ciencias Veterinarias - Universidad Nacional del Litoral (FCV-UNL)

\author{
* Correspondencia: Enrique Formentini, Facultad de Ciencias Veterinarias, Universidad Nacional del Litoral. R.P. Kreder \\ 2805 (3080) Esperanza, Santa Fe, Argentina. \\ E-mail: eforment@fcv.unl.edu.ar
}

Recibido: 20 Febrero 2017. Aceptado: 26 Junio 2017. Disponible en línea: 28 Junio 2017

Editor: L. Frizzo

\begin{abstract}
RESUMEN. En este trabajo se evaluó el efecto de las bacterias persistentes presentes en un inóculo de alta densidad de una cepa autóctona de Escherichia coli sobre la eficacia de enrofloxacina y ciprofloxacina mediante ensayos in vitro de curvas de muerte bacteriana y de determinación de la concentración preventiva de mutantes. En las curvas de muerte realizadas sobre inóculos de alta densidad, ningún antibiótico presentó actividad bactericida y solo permitieron la sobrevida de bacterias persistentes. En el ensayo para determinar la concentración preventiva de mutantes, sobre la superficie del agar de las placas con elevadas concentraciones de enrofloxacina y ciprofloxacina, las bacterias persistentes permanecieron viables sin desarrollar colonias y adoptando morfología filamentosa como una forma de adaptación y supervivencia. Se discute la utilidad clínica de las concentraciones preventivas de mutantes de enrofloxacina y ciprofloxacina sobre $E$. coli ya que, estas elevadas concentraciones permitirían la sobrevida de una subpoblación de bacterias persistentes originando un reservorio biológico que podría dar origen a infecciones crónicas y a favorecer la emergencia de mutantes resistentes.
\end{abstract}

SUMMARY. Effect of persister cells on the efficacy of enrofloxacin and ciprofloxacin against a strain of Escherichia coli. This work evaluated the effect of persister cells present in a high inocula size of a wild strain of Escherichia coli on the efficacy of enrofloxacin and ciprofloxacin by in vitro time-kill curve assays and mutant prevention concentration testing. In time-kill curves performed with high inocula size, no antibiotics showed bactericidal activity, but only allowed the survival of persister cells. In the assay to determine the mutant prevention concentration, on the surface of agar plates containing high enrofloxacin and ciprofloxacin concentrations, persister cells remained viable and without bacterial colonies development and adopting filamentous morphology as a form of adaptation and survival. The clinical usefulness of mutant prevention concentrations of enrofloxacin and ciproflocxacin against Escherichia coli is discussed, as these high concentrations would allow the survival of a sub-population of persister cells originating a biological reservoir that could give rise to chronic infections and favor the emergence of resistant mutants.

Palabras clave: Escherichia coli, bacterias persistentes, concentración preventiva de mutantes.

Key words: Escherichia coli, persister cells, mutant prevention concentration.

\section{Introducción}

En toda población bacteriana sensible a un antibiótico existe la probabilidad de que coexistan bacterias resistentes originadas por una mutación de un solo paso (Lipsitch y Samore, 2002) por lo tanto, el tamaño de una población bacteriana es un factor que puede favorecer la selección de bacterias resistentes (Blondeau, 2009). Este fenómeno cobra importancia, porque en muchas enfermedades infecciosas se pueden hallar altas concentraciones de bacterias en el foco infeccioso, como por ejemplo en el tracto respi-

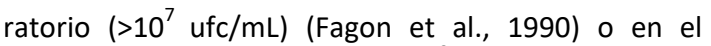
sistema nervioso central $\left(3 \times 10^{8} \mathrm{ufc} / \mathrm{mL}\right.$ ) (Feldman, 1976).

Durante un tratamiento antibiótico, las mutantes resistentes pueden ser seleccionadas dentro de un intervalo de concentraciones donde la más baja es la concentración inhibitoria mínima (CIM) del grueso de la población y la más alta es la CIM de la bacteria que presenta menor sensibilidad al antibiótico. A esta última se la denomina concentración preventiva de mutantes (CPM) y al intervalo entre esta y la CIM se lo conoce como ventana de selección de mutantes (VSM) (Drlica, 2001, 2003). 
La CPM originalmente fue utilizada para evaluar la eficacia de las fluoroquinolonas (FQs) y posteriormente se intentó utilizarla en otros grupos de antibióticos (Smith et al., 2003), siendo actualmente un parámetro de actividad antibacteriana que compite con la CIM en el diseño de esquemas posológicos, al punto que se considera que una terapéutica antibiótica exitosa es aquella que: (i) logra la remisión clínica del cuadro infeccioso, (ii) logra la erradicación del agente infeccioso y (iii) evita el desarrollo de bacterias resistentes. Para lograr estos objetivos es necesario que un esquema posológico permita lograr concentraciones del antibiótico en plasma y en el sitio de acción que sean superiores a la CPM (Blondeau, 2009).

Sin embargo, la exposición in vitro de una población bacteriana a elevadas concentraciones de un antibiótico, da como resultado una cinética de eliminación bacteriana bifásica, donde inicialmente, la población bacteriana sensible es rápidamente eliminada y seguidamente sobrevive un pequeño número de bacterias que se eliminan lentamente (Lewis, 2010). Estas bacterias se denominan persistentes y constituyen una subpoblación capaz de sobrevivir a la exposición de elevadas concentraciones de un antibiótico sin haber desarrollado resistencia a partir de cambios genéticos (Keren et al., 2004).

Por lo tanto, la persistencia bacteriana es una expresión fenotípica y no heredable de una pequeña subpoblación que se origina ya sea de manera espontánea o inducida por factores de estrés medioambiental, entre los que se halla la exposición a los antibióticos (Dörr et al., 2009). En el caso concreto de los antibióticos del grupo de las FQs y en particular de la ciprofloxacina (CFX), se ha demostrado que estos son agentes capaces de inducir el estado de persistencia bacteriana y que de esta manera su empleo indiscriminado contribuye a reducir su eficacia (Lewis, 2010).

Se ha propuesto que las persistentes presentan lento crecimiento, que no crecen, (Balaban et al., 2004) o que se hallan temporalmente en un estado de inactividad biológica que les permite escapar a la acción letal de los antibióticos, porque los sitios de acción de estos estarían inactivados a causa de la disminuida actividad metabólica de estas (Lewis, 2007).

Sin embargo, el crecimiento bacteriano y la persistencia no son incompatibles ya que, las persistentes presentan actividad metabólica que se manifiesta con la sobreexpresión y el aumento de la actividad de las bombas de eflujo, que reducen de manera significativa las concentraciones de los antibióticos en el interior de las bacterias (Pu et al., 2016). También las persistentes son capaces de replicarse y que la aparente estabilidad de su población es el resultado de un equilibrio dinámico entre la muerte y la replicación bacteriana (Wakamoto et al., 2013).

El impacto clínico de las persistentes es que estas contribuyen a la patogénesis de muchas infecciones que requieren tratamientos antibióticos prolongados y son la causa de cuadros clínicos recurrentes. De esta manera las persistentes pueden afectar negativamente el éxito de una terapéutica antibiótica (Cohen et al., 2013).

En vista de lo expresado, el objetivo de este trabajo fue evaluar in vitro el efecto de las persistentes presentes en una cepa autóctona de Escherichia coli sobre: (i) la eficacia de enrofloxacina (EFX) y CFX sobre inóculos de conteo bacteriano estándar y elevado mediante ensayos de curvas de muerte bacteriana $y$ (ii) evaluar el efecto de la CPM de EFX y CFX sobre la sobrevida de las persistentes.

\section{Materiales y Métodos}

\section{Microorganismo, antibióticos y medios de cultivo}

Se utilizó una cepa autóctona de E. coli aislada de un ternero con signos de gastroenteritis, identificada por PCR (Frank et al., 1998) que fue denominada E. coli 09684. Los antibióticos consistieron en estándares de EFX y CFX de pureza conocida (Sigma-Aldrich ${ }^{\circledR}$ Argentina). Los medios de cultivos utilizados fueron caldo Mueller Hinton (Britania, Argentina). Como medio de cultivo selectivo para el desarrollo de enterobacterias se utilizó agar Mac Conkey (Britania, Argentina) y como medio selectivo para aislamiento e identificación de E. coli se utilizó agar TBX (Biokar Diagnostics, Francia). Los medios de cultivo utilizados para la identificación de $E$. coli mediante pruebas bioquímicas fueron: T.S.I. agar (Britania, Argentina), SIM medio (Britania, Argentina) y Simmons Citrato Agar (Britania, Argentina).

\section{Inóculos de concentración bacteriana estándar}

Los inóculos de concentración bacteriana estándar se prepararon a partir de colonias incubadas durante 24 h sobre placas de agar Mac Conkey. Los microorganismos fueron suspendidos en solución isotónica estéril hasta lograr una turbidez equivalente a un valor de 0,5 de la escala de McFarland $\left(1 \times 10^{8}\right.$ unidades formadoras de colonia $[\mathrm{ufc}] / \mathrm{mL}$ ).

\section{Inóculos de concentración bacteriana elevada}

La construcción de los inóculos de concentración bacteriana elevada se realizó según el procedimiento descripto por Blondeau et al. (2009). La superficie de tres placas con agar Mac Conkey fueron sembradas con un hisopo estéril humedecido en un inóculo de $E$. coli 09-684 de concentración bacteriana estándar (1 x $10^{8} \mathrm{ufc} / \mathrm{mL}$ ) y que posteriormente se incubaron a $35^{\circ} \mathrm{C}$. Al día siguiente, todo el contenido bacteriano de la superficie de las placas fue removido con ayuda de una espátula estéril y transferido a un frasco conte- 
niendo $100 \mathrm{~mL}$ de caldo Mueller Hinton. Esta suspensión fue colocada en estufa a $35^{\circ} \mathrm{C}$ durante $24 \mathrm{~h}$.

\section{Determinación de los valores de CIM de EFX y CFX}

Los valores de CIM de EFX y CFX se estimaron con el método de macrodilución en tubo (CLSI, 2008) en caldo Mueller Hinton. El medio de cultivo se preparó según instrucciones del fabricante y fue esterilizado a $121^{\circ} \mathrm{C}$ durante 15 minutos. El medio fue preparado el día anterior a la realización de los ensayos y hasta el momento de su uso fue almacenado en refrigerador a $7^{\circ} \mathrm{C}$. Los valores de CIM de EFX y CFX se determinaron por triplicado dentro de un intervalo de concentraciones comprendidas entre 0,0039 y $1 \mu \mathrm{g} / \mathrm{mL}$, sobre un inóculo con una concentración bacteriana final aproximada de $0,5 \times 10^{6} \mathrm{ufc} / \mathrm{mL}$. (García rodríguez et al., 2001). La CIM se determinó como la menor concentración de antibiótico que inhibió el crecimiento visible de bacterias y para cada antibiótico fue fijada como el mayor valor observado de las tres series de diluciones realizadas.

\section{Construcción de curvas de crecimiento y muerte bacteriana}

Las curvas de crecimiento y muerte bacteriana de $E$. coli 09-684 en presencia de EFX y CFX se realizaron sobre: (i) inóculos de conteo bacteriano estándar, siendo de $0,5 \times 10^{6} \mathrm{ufc} / \mathrm{mL}$ para EFX y CFX e (ii) inóculos de conteo bacteriano elevado, siendo de $6,7 \mathrm{x}$ $10^{8} \mathrm{ufc} / \mathrm{mL}$ para EFX y de $3,6 \times 10^{8} \mathrm{ufc} / \mathrm{mL}$ para CFX.

En las curvas de crecimiento los inóculos de bajo y alto conteo bacteriano fueron incubados a $35^{\circ} \mathrm{C}$ durante 24 h. De éstos se extrajeron alícuotas de $100 \mu \mathrm{L}$ a los siguientes tiempos: $0,1,2,3,5,10$ y $24 \mathrm{~h}$. Cada una de esas alícuotas fue diluida en solución fisiológica estéril y $100 \mu \mathrm{L}$ fueron extendidos sobre la superficie de una placa de agar Mac Conkey. Las diluciones de cada tiempo de muestreo fueron sembradas por duplicado. En todos los casos las placas se incubaron en estufa a $35^{\circ} \mathrm{C}$ durante $24 \mathrm{~h}$, luego de lo cual se procedió al conteo de ufc/placa.

En las curvas de muerte en presencia de EFX y CFX, los inóculos de conteo bacteriano estándar y elevado fueron expuestos a concentraciones equivalentes a: 0,25 , $0,5,1,2,4,8$ y 32 x CIM de cada antibiótico e incubados a $35^{\circ} \mathrm{C}$ durante $24 \mathrm{~h}$. De los inóculos expuestos a cada concentración de antibiótico fueron extraídas alícuotas de $100 \mu \mathrm{L}$ a los siguientes tiempos: 0, 1, 2, $3,5,5,10$ y $24 \mathrm{~h}$. Cada una de esas alícuotas fue diluida en solución fisiológica estéril y $100 \mu \mathrm{L}$ fueron extendidos sobre la superficie de una placa de agar Mac Conkey. Cada dilución fue sembrada por duplicado. En todos los casos las placas se incubaron en estufa a $35^{\circ} \mathrm{C}$ durante $24 \mathrm{~h}$, luego de lo cual se procedió al conteo de ufc/placa.
El número de ufc/mL de cada tiempo de muestreo en las curvas de crecimiento y muerte se determinó multiplicando el número de ufc/placa por el factor derivado de las diluciones de cada muestra. Dado que cada muestra se realizó por duplicado, el número de ufc $/ \mathrm{mL}$ resultante se expresó como valor promedio. El límite de detección fue de $10 \mathrm{ufc} / \mathrm{mL}$. A fin de facilitar la representación gráfica y la interpretación de las curvas, el conteo bacteriano en cada tiempo de muestro se expresó como $\log _{10}$ ufc/mL.

\section{Criterios de eficacia}

Para cuantificar la eficacia antibacteriana de EFX y CFX sobre los inóculos de conteo bacteriano estándar $(0,5$ $x 10^{6} \mathrm{ufc} / \mathrm{mL}$ ), se utilizaron tres niveles de actividad antibacteriana: bacteriostática, bactericida y erradicación bacteriana reportados (Sidhu et al. 2010).

La acción bacteriostática se definió como las concentraciones de antibiótico que no produjeron ningún cambio en el conteo bacteriano inicial luego de $24 \mathrm{~h}$ de incubación.

La acción bactericida se definió como una reducción de $3 \log _{10}$ respecto del $\log _{10}$ del conteo bacteriano inicial $\left(-3 \log _{10}\right)$, que equivale a una reducción del $99,9 \%$ del mismo.

La erradicación bacteriana se definió como una reducción de $4 \log _{10}$ respecto del $\log _{10}$ del conteo bacteriano inicial $\left(-4 \log _{10}\right)$, que equivale a una reducción del $99,99 \%$ del mismo.

Considerando que un conteo bacteriano inicial estandarizado de $0,5 \times 10^{6} \mathrm{ufc} / \mathrm{mL}$ equivale a 500.000 ufc/mL (García rodríguez et al., 2001), una reducción del $99,9 \%\left(-3 \log _{10}\right)$ y $99,99 \%\left(-4 \log _{10}\right)$, equivalen a conteos bacterianos de 500 y $50 \mathrm{ufc} / \mathrm{mL}$ respectivamente, los que se asocian con una actividad bactericida (remisión clínica) y la erradicación bacteriana (cura bacteriológica) respectivamente.

En el caso de los inóculos de conteo bacteriano elevado, aunque una reducción de $-3 \log _{10} 0-4 \log _{10}$, se corresponden con reducciones del conteo inicial del $99,9 \%$ y el $99,99 \%$, el número de bacterias sobrevivientes es casi tan elevado como el conteo bacteriano inicial de un inóculo de conteo bacteriano estándar $(\approx 500.000 \mathrm{ufc} / \mathrm{mL})$, cifra que estaría lejos de ser relacionada con una remisión clínica o una cura bacteriológica. Por esta razón, para cuantificar la eficacia antibacteriana de EFX y CFX sobre estos inóculos se modificaron los puntos de corte según el criterio sugerido por Baroni et al. (2014).

Para definir la actividad bacteriostática se tomó como referencia el conteo bacteriano inicial de $6,7 \times 10^{8}$ $\mathrm{ufc} / \mathrm{mL}$ para EFX y de $3,6 \times 10^{8} \mathrm{ufc} / \mathrm{mL}$ para CFX, por lo que ésta fue definida como la ausencia de eficacia, es decir cuando la diferencia el conteo bacteriano a las 24 $h$ y el conteo bacteriano inicial era cero $(E=0)$. 
La actividad bactericida fue definida como la reducción del conteo inicial hasta un valor equivalente a un conteo bacteriano igual a $500 \mathrm{ufc} / \mathrm{mL}$ cuyo $\log _{10}$ es 2,7 .

La actividad asociada a la erradicación bacteriana fue definida como la reducción del conteo inicial hasta un valor equivalente a un conteo bacteriano igual a 50 ufc/mL cuyo $\log _{10}$ es 1,7 .

\section{Determinación de los valores de CPM de EFX y CFX}

Con cada antibiótico (EFX o CFX) se prepararon placas de agar Mac Conkey conteniendo concentraciones equivalentes a $0,1,4,14,24,34,44,54$ y 64 x CIM. Cada serie de concentraciones se preparó por cuadruplicado. Sobre la superficie de cada una de las placas se extendieron $100 \mu \mathrm{L}$ de un inóculo de concentración bacteriana elevada elevada $\left(7,7 \times 10^{8} \mathrm{ufc} / \mathrm{mL}\right)$. Todas las placas se incubaron a $35^{\circ} \mathrm{C}$ durante $48 \mathrm{~h}$. La CPM se determinó como la mayor concentración de antibiótico que inhibió el desarrollo de colonias bacterianas.

\section{Delimitación ex post la VSM de EFX y CFX}

La VSM de EFX y CFX se delimitó sobre los perfiles simulados de concentración plasmática de cada antibiótico que se obtendrían tras la administración en bovinos de una dosis terapéutica de $5 \mathrm{mg} / \mathrm{kg}$ de EFX. La simulación de realizó con el software ADAPT II (BMSR, University of Southern California, USA) utilizando los parámetros farmacocinéticos de EFX y CFX reportados por de Lucas et al. (2008).

Para cada antibiótico se estimó el tiempo durante el cual las concentraciones plasmáticas se hallaron por encima de la CPM y el tiempo durante el cual se extendió la VSM.

\section{Aislamiento e identificación de bacterias en placas con antibiótico y sin desarrollo bacteriano}

Para determinar la presencia de bacterias viables sobre la superficie de las placas que no presentaron desarrollo de colonias en el ensayo de CPM, se tomaron muestras de la superficie de cada una de las placas con las que se realizaron improntas para tinción de Gram y microscopía y las pruebas bioquímicas (Agar T.S.I., SIM Medio y Simmons Citrato Agar) para confirmar la identidad de E. coli.

Las bacterias aisladas de la superficie del agar se sembraron en agar TBX para confirmación de la identidad de E. coli. A partir de las colonias que desarrollaron en agar TBX, se realizó tinción de Gram y microscopía y las pruebas bioquímicas para confirmar la identidad de E. coli (Agar T.S.I., SIM Medio y Simmons Citrato Agar). De todas las colonias que desarrollaron en agar TBX, se seleccionaron al azar cinco y para cada una de ellas se determinó la CIM para EFX y CFX.

\section{Resultados}

Los valores de CIM de EFX y CFX para E. coli 09-684 fueron de 0,0312 y $0,0156 \mu \mathrm{g} / \mathrm{mL}$, respectivamente, los que según la base de datos del European Committe on Antimicrobial Susceptibility Testing (EUCAST) esta cepa de E. coli es sensible a EFX y CFX. La representación gráfica de las curvas de muerte de $E$. coli 09684 expuestas a EFX y CFX realizadas con inóculos de conteo bacteriano estándar y elevado se presentan en la Figura 1.

La inspección visual de las gráficas semilogarítmicas de todas las curvas de muerte de E. coli 09-684, mostró que la mayoría de las concentraciones de EFX y CFX mayores a la CIM, originaron cinéticas bactericidas que presentaron una primera fase de eliminación bacteriana rápida ( 0 a 3-5 h), que fue seguida de una fase de eliminación bacteriana lenta (3-5 h hasta $24 \mathrm{~h}$ ). Asumiendo que la cinética de eliminación bacteriana puede ser descripta por un proceso de orden uno (un término exponencial), las dos fases de eliminación bacteriana pueden ser descriptas por dos procesos de eliminación de orden uno consecutivos (dos términos exponenciales), lo que implica la existencia de un cambio en la velocidad de eliminación bacteriana. Esta segunda fase de eliminación (área sombreada de las gráficas de la Fig. 1), puede ser asociada con la lenta eliminación de una sub-población de bacterias persistentes.

El tamaño del inóculo afectó la eficacia antibacteriana de EFX y CFX. En términos generales, en presencia de un conteo bacteriano estándar, CFX mostró ser más efectiva que EFX ya que, a diferencia de esta, todas las concentraciones mayores a su CIM lograron reducir el conteo bacteriano hasta niveles compatibles con la erradicación bacteriana (Fig. 1A-B).

En presencia de conteos bacterianos elevados, las bacterias persistentes que sobrevivieron a la exposición de elevadas concentraciones de EFX y CFX durante $24 \mathrm{~h}$, presentaron conteos bacterianos de valores muy cercanos a los conteos iniciales observados en las curvas de crecimiento construidas con inóculos de conteos bacterianos estándar (Fig. 1).

Los valores estimados de CPM fueron $0,407 \mu \mathrm{g} / \mathrm{mL}$ para EFX $(14 \times \mathrm{CIM})$ y de $0,202 \mu \mathrm{g} / \mathrm{mL}$ para CFX $(14 \mathrm{x}$ CIM). Sin embargo de la superficie de las placas de agar con antibiótico que no presentaron desarrollo bacteriano visible, se aislaron bacterias Gram negativas de aspecto filamentoso (Fig. 2 $\mathrm{B}_{1}-\mathrm{B}_{2}$ ). El cultivo de estas bacterias en medios de crecimiento selectivos para E. coli (agar TBX) y los resultados de las pruebas bioquímicas arrojaron resultados compatibles con E. coli. También se observó que estas bacterias retomaron su morfología original de cocobacilo Gram negativo (Fig. $2 \mathrm{C}_{1}-\mathrm{C}_{2}$ ), y presentaron los mismos valores de CIM para EFX y CFX que las bacterias del inóculo que les dio origen. 

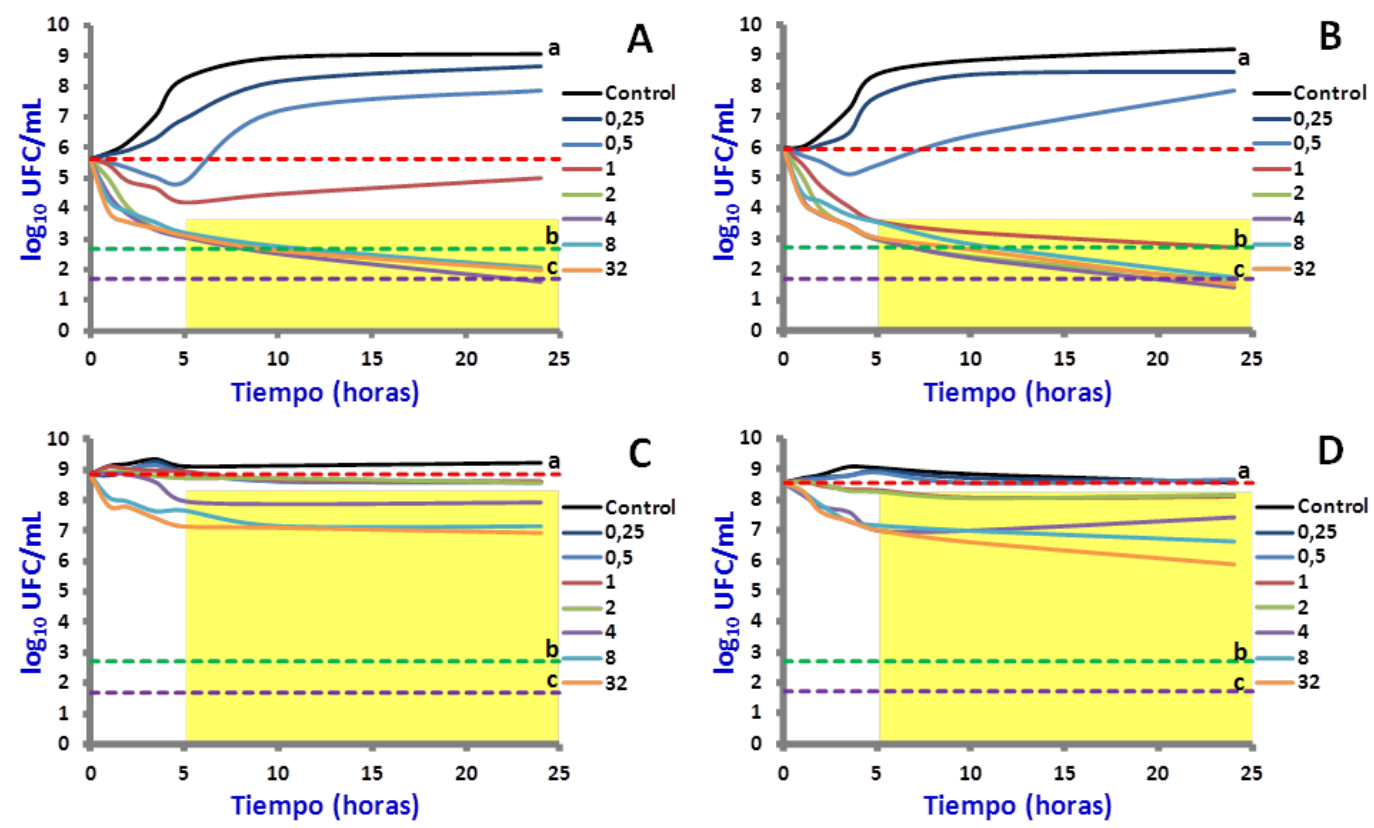

Figura 1. Representación gráfica en escala semilograrítmica de la evolución temporal del conteo de bacterias viables de E. coli 09-684 luego de exponer un inóculo de conteo bacteriano estándar $\left(0,5 \times 10^{6} \mathrm{ufc} / \mathrm{mL}\right)$ a concentraciones de (A) enrofloxacina y (B) ciprofloxacia. Evolución temporal del conteo de bacterias viables luego de exponer un inóculo de conteo bacteriano elevado a concentraciones de (C) enrofloxacina $\left(7,6 \times 10^{8} \mathrm{ufc} / \mathrm{mL}\right)$ y (D) ciprofloxacina $\left(3,6 \times 10^{8} \mathrm{ufc} / \mathrm{mL}\right)$. Los puntos de corte de eficacia clínica están representados con líneas de puntos horizontales siendo (a) actividad bacteriostática, (b) actividad bactericida y (c) erradicación bacteriana. En cada uno de los ensayos, la curva control corresponde al desarrollo bacteriano en ausencia de antibiótico y los valores de las leyendas de cada curva corresponden a las concentraciones de enrofloxacina y ciprofloxacina expresadas como $\mu \mathrm{g} / \mathrm{mL}$.

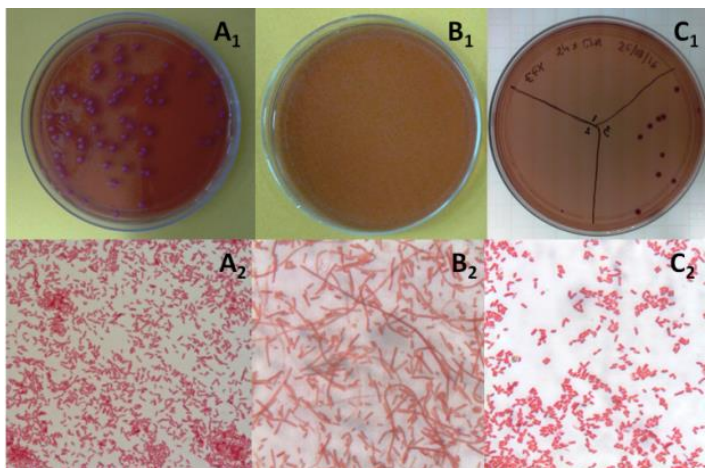

Figura 2. $\left(\mathbf{A}_{1}\right)$ Colonias de $E$. coli $09-684$ sobre una placa de agar presentando en $\left(\mathbf{A}_{\mathbf{2}}\right)$ la morfología de cocobacilo Gram negativo. ( $\left.\mathbf{B}_{1}\right)$ Ausencia de desarrollo de colonias de E. coli sobre una placa de agar conteniendo elevadas concentraciones de enrofloxacina y $\left(\boldsymbol{B}_{2}\right)$ tinción de un hisopado de la superficie de misma placa mostrando bacterias Gram (-) con morfología filamentosa. $\left(\mathbf{C}_{1}\right)$ Colonias de $E$. coli obtenidas por cultivo de una muestra obtenida de la superficie de la placa de la figura $B_{1}$, mostrando la viabilidad de las formas filamentosas persistentes de $E$. coli 09-684 y $\left(\mathbf{C}_{2}\right)$ y el retorno a la morfología de cocobacilo Gram (-).

Los límites de la VSM se hallan indicados en los perfiles simulados de concentración plasmática de EFX y CFX que se presentan en la figura 3, donde puede observarse que tanto para EFX como para CFX, las concentraciones plasmáticas de cada antibiótico que se hallan por encima de la CPM se mantienen durante poco tiempo, dentro de un intervalo comprendido entre 0,35 y $3,21 \mathrm{~h}$ para EFX y de 0,99 y $5,72 \mathrm{~h}$ para CFX.

Esto determina que tras la administración en bovinos de una dosis terapéutica recomendada de $5 \mathrm{mg} / \mathrm{kg}$ de $E F X$, el tiempo en el que las concentraciones se hallarían por encima de la CPM ( $\mathrm{t}>\mathrm{CPM}$ ) y que prevendrían la emergencia de cepas resistentes sería de 2,86 h para EFX y de $4,73 \mathrm{~h}$ para CFX. Por otra parte, las VSM para EFX y CFX se extendiieron hasta las 12 y $15 \mathrm{~h}$ posadministración respectivamente.

\section{Discusión}

Uno de los grupos de antibióticos de amplio espectro que más se utiliza hoy en día es el de las FQs. Los antibióticos de este grupo se unen a las enzimas ADN girasa y topoisomerasa IV que son las encargadas de regular el superenrollamiento de las cadenas de ADN durante la replicación y la transcripción del mismo (Drlica \& Zhao, 1997; Wang, 2002).

Aunque las FQs son antibióticos bactericidas potentes, éstos no pueden esterilizar un medio de cultivo, ya que aunque la mayoría de la población bacteriana es rápidamente eliminada, una pequeña sub-población 
de bacterias persistentes refractaria a la acción de las FQs sobrevive, probablemente debido a una disminuida actividad de la ADN girasa y la topoisomerasa IV a causa de su lento crecimiento o su inactividad metabólica (Lewis, 2007).

Los resultados obtenidos en este estudio, muestran que las bacterias persistentes afectaron la eficacia de EFX y CFX sobre inóculos de E. coli 09-684 de conteo bacteriano elevado ya que, en las curvas de muerte realizadas con éstos (Fig. 1C-D) se observó que en presencia de concentraciones de EFX y CFX mayores a $4 \times \mathrm{CIM}$ no se produjo el reinicio del crecimiento bacteriano.

Si bien este resultado permite inferir que estas concentraciones de EFX y CFX evitaron in vitro la selección de cepas resistentes, también demuestra que no fueron efectivas para eliminar las bacterias persistentes, cuyo conteo se mantuvo casi constante durante las $24 \mathrm{~h}$ que duraron los ensayos y que no fue compatible con ningún tipo de eficacia bacteriológica.
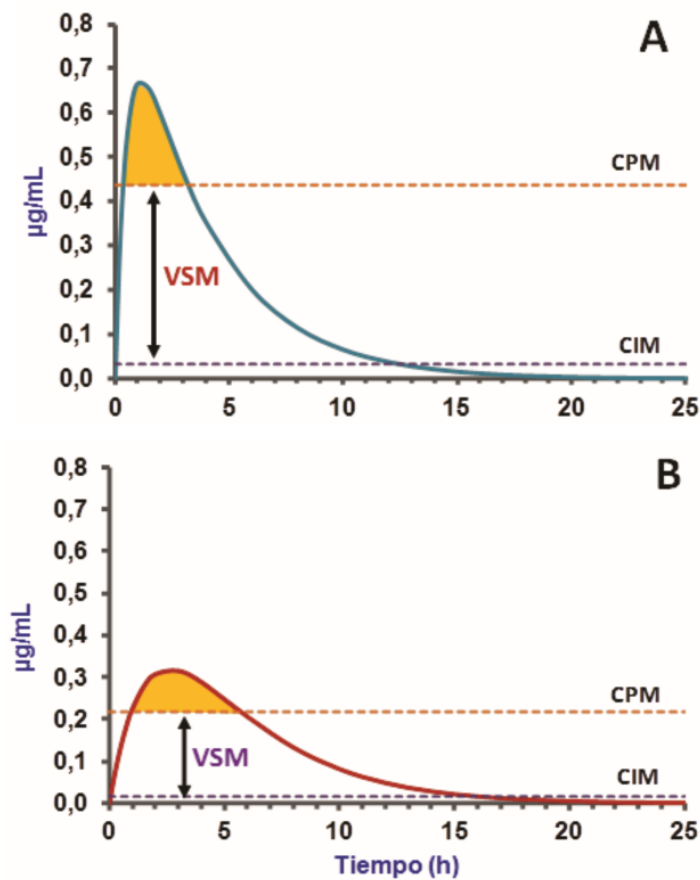

Figura 1. Delimitación ex post de la Ventana de Selección de Mutantes (VSM) para E. coli 09-684 de (A) enrofloxacina y (B) ciprofloxacina sobre los perfiles simulados de concentración plasmática de cada antibiótico que se obtendrían tras la administración de una dosis única de $5 \mathrm{mg} / \mathrm{kg}$ de enrofloxacina a un bovino. Cada VSM está delimitada por líneas de puntos que indican la concentración inhibitoria mínima (CIM) y la concentración preventiva de mutantes (CPM). Las áreas sombreadas indican las concentraciones que evitarían el desarrollo de bacterias mutantes resistentes. Los perfiles de concentración plasmática EFX y CFX se simularon con el software ADAPT II (BMSR, University of Southern California, USA), utilizando los parámetros farmacocinéticos de EFX y CFX reportados por de Lucas et al. (2008).
En el ensayo de CPM se observó un fenómeno similar cuando se determinó la presencia de E. coli 09-684 de morfología filamentosa sobre la superficie de las placas de agar que no presentaban desarrollo de colonias.

Aunque no fue posible determinar el número de bacterias viables presentes sobre la superficie de estas placas, se demostró por medio del aislamiento y repique sobre medios de cultivo selectivos, que estas bacterias se mantuvieron viables aun luego de permanecer durante $48 \mathrm{~h}$ en contacto con concentraciones de EFX y CFX de hasta 64 x CIM.

El escaso efecto que el tiempo de exposición a EFX y CFX tuvo sobre la sobrevida de las bacterias persistentes, debería conducirnos a reconsiderar la utilidad de la CPM de estos antibióticos en particular y de las FQs en general, en el diseño de los regímenes terapéuticos destinados a limitar la emergencia de cepas resistentes.

Respecto a este punto, son muchos los autores que opinan que el tiempo de exposición a concentraciones iguales o mayores a la CPM ( $\mathrm{t}>\mathrm{CPM}$ ) es determinante para evitar la selección de las bacterias resistentes que están presentes en la población bacteriana antes de la exposición al antibiótico (Hansen et al., 2003).

Sin embargo, en el estudio ex post, donde se delimitó la VSM en los perfiles simulados de EFX y CFX, obtenidos tras la administración bovinos de una dosis terapéutica de EFX, pudo observarse una falta de concordancia entre el tiempo de exposición del inóculo para la determinación in vitro de la CPM (48 h) y el tiempo estimado de exposición in vivo, en el que los valores estimados de $\mathrm{t}>\mathrm{CPM}$ fueron de $2,86 \mathrm{~h}$ para EFX y $4,73 \mathrm{~h}$ para CFX, los que representan un breve lapso de tiempo si tomamos como referencia el intervalo entre dosis de $24 \mathrm{~h}$ sugerido para EFX. Otro dato controvertido lo constituye el hecho de que los valores estimados de $\mathrm{t}>\mathrm{CPM}$ de EFX y CFX son muy cortos con respecto al tiempo estimado durante el cual se prolonga la VSM que fue de $12 \mathrm{~h}$ para EFX y $15 \mathrm{~h}$ para CFX, siendo que justamente éste sería el tiempo más crítico durante el cual habría mayores posibilidades de selección y desarrollo de una cepa bacteriana con menor sensibilidad a estos antibióticos.

En base a los resultados obtenidos en este estudio, creemos que hay cuatro aspectos que se deberían considerar cuando se analiza la utilidad clínica de la CPM de EFX y CFX en particular.

El primero se refiere al alcance de la eficacia de la CPM de este tipo de antibióticos, la cual solo evita el desarrollo de las cepas bacterianas menos sensibles a éstos, lo cual tiene un límite que está dado por la máxima dosis del antibiótico que puede recibir un individuo, para que las concentraciones logradas por éste no superen los niveles hemáticos compatibles con la aparición de signos de toxicidad. Considerando ese 
escenario, la CPM sería ineficaz para evitar el desarrollo de las cepas bacterianas que necesitaran concentraciones antibióticas tóxicas para ser eliminadas.

El segundo es que las concentraciones de antibiótico iguales o mayores a la CPM no solamente carecen de actividad sobre las bacterias persistentes sino que las FQs, y en particular la CFX, son capaces de inducir el estado de persistencia bacteriana (Theodore et al., 2013).

El tercero es que la eficacia de la CPM se manifiesta cuando los antibióticos actúan sobre poblaciones bacterianas de conteos elevados que se asemejan a las cargas bacterianas que se hallan en ciertas infecciones. Sin embargo, esta eficacia no se manifestaría en las infecciones de que cursan con conteos bacterianos menores.

El cuarto deriva del anterior y es que, aunque un foco infeccioso con alta densidad bacteriana fuese expuesto a concentraciones iguales o mayores a la CPM durante un tiempo adecuado, estas concentraciones no serían efectivas para reducir la carga bacteriana a niveles compatibles con la remisión clínica ni con la erradicación bacteriana.

Respecto de la sobrevida de las bacterias persistentes en condiciones medioambientales adversas como la exposición a los antibióticos, se ha demostrado que durante el estado de persistencia la actividad biológica de las bacterias y su replicación continúan. Esto ha permitido postular la hipótesis de que, ante situaciones de stress ambiental, la persistencia sería un estado de evolución intermedio para la elaboración de una resistencia heredable (Cohen et al., 2013). En efecto, se ha demostrado que durante el estado de persistencia el genoma de las bacterias es más inestable y propenso a los cambios espontáneos -"mutaciones adaptativas"-, como así también es más propenso de adquirir resistencia a través del intercambio horizontal de genes (Beaber et al., 2004).

La presencia de formas filamentosas de E. coli 09-684 sobre la superficie de las placas de agar sin desarrollo de colonias en el ensayo para determinar la CPM de EFX y CFX, se correlaciona con el fenómeno de persistencia observado en las curvas de muerte construidas con inóculos de conteo bacteriano elevado.

La morfología de E. coli puede modificarse a causa de la exposición tanto a condiciones ambientales no favorables como a moléculas de antibióticos (Young, 2006). La filamentación es un fenómeno frecuente de observar en muchas especies bacterianas y ocurre cuando se bloquea la replicación, pero el proceso de crecimiento continúa, y constituye una estrategia de supervivencia tendiente promover el crecimiento y la sobrevida de la población bacteriana en los tejidos del hospedador (Baorto et al., 1997; Justice, et al., 2006) y a evitar la fagocitosis por parte de las células de su sistema inmune (Möller et al., 2012).

En este estudio, la presencia de formas filamentosas de E. coli 09-684, representarían otra faceta de la persistencia bacteriana ya que, las bacterias con esta morfología pudieron sobrevivir y mantenerse viables aún expuestas a elevadas concentraciones de EFX y CFX durante $48 \mathrm{~h}$.

Möller et al. (2013) demostraron que las formas bacterianas filamentosas constituyen un estado morfológico transitorio ya que, observaron que cuando las concentraciones de antibióticos descienden a niveles sub-inhibitorios, la división celular se reinicia y los filamentos se fragmentan en bacterias viables de morfología normal. Ese reporte guarda similitud con los resultados observados en este trabajo ya que, cuando las formas filamentosas fueron repicadas en un medio de cultivo sin antibiótico, se reinició el crecimiento bacteriano dando origen a colonias, cuyas bacterias presentaron morfología y perfil bioquímico concordantes con $E$. coli.

Concluyendo, tanto en las curvas de muerte bacteriana como en el ensayo para determinar la CPM sobre placas de agar, las elevadas concentraciones de EFX y CFX que son antibióticos bactericidas y con actividad concentración dependiente, no solo contribuyeron la selección de un reservorio biológico para la posible emergencia de mutantes resistentes, sino que además, su presencia posiblemente estimuló el pleomorfismo de $E$. coli 09-684, tornando su morfología de cocobacilos a filamentos como una forma de adaptación y supervivencia.

Estos hallazgos deberían hacernos reconsiderar cual es el verdadero impacto clínico de la CPM como un nuevo parámetro de eficacia antibacteriana para prevenir la emergencia de mutantes resistentes.

Desde el inicio de la era antibiótica hasta nuestros días se ha buscado optimizar el empleo de los antibióticos a fin de frenar el avance de la resistencia bacteriana. Dentro de este contexto histórico surge el concepto de la CPM, que sin embargo, constituye una variante reforzada del principio de "cuanto más, mejor" y que lejos de aportar una solución a la emergencia de bacterias resistentes, podría contribuir a la misma, por lo que su utilidad clínica debería ser reconsiderada.

En el área de la medicina y particularmente en el área de la farmacología, existe la necesidad de optimizar el empleo de los antibióticos ya existentes. Estamos muy lejos de haber logrado eso y la explicación radica en que las bacterias ya han desarrollado resistencia a todos los mecanismos de acción de todos los antibióticos conocidos. Lo nuevo de nuestro arsenal terapéutico está constituido por nuevas generaciones de las viejas familias de antibióticos y no disponemos de nuevos mecanismos de acción para hacer frente al avance de la resistencia bacteriana. 
Dentro de ese contexto, la posibilidad de que las bacterias persistentes sean la etiología de enfermedades bacterianas crónicas o recidivantes y que éstas constituyan reservorios biológicos a partir de los cuales podrían emerger mutantes resistentes, destaca la importancia y la necesidad de desarrollar en un futuro próximo drogas para erradicar estas sub-poblaciones bacterianas.

En este sentido, los esfuerzos están encaminados al desarrollo de moléculas que las eliminen de manera directa o que reviertan su aparente estado de inactividad biológica, haciéndolas nuevamente sensibles a los mecanismos de acción de los antibióticos convencionales. Este tipo de terapia lograría evitar los cuadros clínicos recidivantes, acortar los tiempos de tratamiento y los tiempos de exposición de las bacterias a los antibióticos, reduciendo así el riesgo de la selección de mutantes resistentes.

Un esquema terapéutico alternativo podría estar constituido por una combinación compuesta de antibióticos convencionales que eliminen las bacterias que se encuentran en fase de crecimiento y los nuevos fármacos que cuya acción estaría dirigida hacia las bacterias en estado de persistencia.

\section{Agradecimientos}

Este estudio pudo realizarse gracias al soporte económico proporcionado por la Universidad Nacional del Litoral, Argentina, en el marco de la convocatoria de proyectos CAI+D 2011. Los autores también agradecen al Dr. Marcelo Aubagna de la cátedra de Infectología y Enfermedades Infecciosas FCV-UNL y al Dr. Laureano Frizzo y a su grupo de colaboradores del Laboratorio de Análisis de Alimentos (LAA), ICiVet Litoral Conicet-UNL, por la valiosa colaboración prestada para la realización de este trabajo.

\section{Bibliografía}

Álvarez I, Raia A, Porta N, Delgado F, Carosio A, Trono K, Balaban NQ, Merrin J, Chait R, Kowalik L, Leibler S. 2004. Bacterial persistence as a phenotypic switch. Science 305:1622-1625.

Baorto DM, Gao Z, Malaviya R, Dustin ML, van der Merwe A, Lublin DM, Abraham SN. 1997. Survival of FimH-expressing enterobacteria in macrophages relies on glycolipid traffic. Nature 389: 636-639.

Baroni E, Russi N, Rubio M, Picco E, Formentini E. 2014. Actividad antibacteriana in vitro de ciprofloxacina sobre Escherichia coli: efecto del suero bovino y tamaño del inóculo. InVet 16(1): 7-14.

Beaber JW, Hochhut B, Waldor MK. 2004. SOS response promotes horizontal dissemination of antibiotic resistance genes. Nature 427:72-74.
Blondeau JM. 2009. New concepts in antimicrobial susceptibility testing: the mutant prevention concentration and mutant selection window approach. Vet Dermatol. 20:383-396.

CLSI (Clinical and Laboratory Standards Institute). 2008. Development of in vitro susceptibility testing criteria and quality control parameters for veterinary antimicrobial agents; Approved guideline. 3rd Edition, Document M37-A3, Volume 28, Number 7. Wayne, Pennsylvania USA.

Cohen NR, Lobritz MA, Collins JJ. 2013. Microbial persistence and the road to drug resistance. Cell. Host. Microbe 13: 632642.

de Lucas JJ, San Andrés MI, González F, Froyman R, Rodríguez C. 2008. Pharmacokinetic behaviour of enrofloxacin and its metabolite ciprofloxacin after subcutaneous administration in cattle. Vet Res Commun. 32:275-9.

Dörr T, Lewis K, Vulić M. 2009. SOS Response Induces Persistence to Fluoroquinolones in Escherichia coli. Plos. Genet. 5: 1-9.

Drlica K, Zhao X. 1997. DNA gyrase, topoisomerase IV, and the 4-quinolones. Microbiol. Mol. Biol. Rev. 61: 377-392.

Drlica K. 2001. A strategy for fighting antibiotic resistance. ASM News 67: 27-33.

Drlica K. 2003. The mutant selection window and antimicrobial resistance. J Antimicrob Chemother. 52: 11-7.

European Committee on Antimicrobial Susceptibility Testing. Data from the EUCAST MIC distribution website, last accessed 28- 4- 2017. "http://www.eucast.org"

Fagon JY, Chastre J, Trouillet JL, Domart Y, Dombret MC, Bornet M, Gibert C. 1990. Characterization of distal bronchial microflora during acute exacerbation of chronic bronchitis. Use of the protected specimen brush technique in 54 mechanically ventilated patients. Am Rev Respir Dis.142: 1004-1008.

Feldman W. 1976. Concentrations of bacteria in cerebrospinal fluid of patients with bacterial meningitis. J Pediatr. 88: 549452.

Franck SM, Bosworth BT, Moon HW. 1998. Multiplex PCR for enterotoxigenic, attaching and effacing, and Shiga toxinproducing Escherichia coli strains from calves. J Clin Microbiol. 36: 1795-1797.

García Rodríguez J, Cantón R, García Sánchez J, Gómez-Lus M, Martínez Martínez L, Rodríguez-Avial C, Vila J. 2001. Métodos Especiales para el Estudio de la sensibilidad a los Antimicrobianos. En Juan J. Picazo Editor: Procedimientos en Microbiología Clínica; SEIMC Sociedad Española de Enfermedades Infecciosas y Microbiología Clínica. Primera Edición. 38 pp.

Hansen G, Metzler KL, Drlica K, Blondeau J. 2003. Mutant prevention concentration of gemifloxacin for clinical isolates of Streptococcus pneumoniae. Antimicrob Agents Chemother. 47: 440-441.

Justice SS, Hunstad DA, Seed PC, Hultgren SJ. 2006. Filamentation by Escherichia coli subverts innate defenses during urinary tract infection. Proc. Natl. Acad. Sci. 103: 19884-19889

Keren I, Kaldalu N, Spoering A, Wang Y, Lewis K. 2004. Persister cells and tolerance to antimicrobials. FEMS Microbiol. Lett. 230: 13-8. 
Lewis K. 2007. Persister cells, dormancy and infectious disease. Nat. Rev. Microbiol. 5: 48-56.

Lewis K. 2010. Persister cells. Annu. Rev. Microbiol. 64: 357372.

Lipsitch M, Samore MH. 2002. Antimicrobial use and antimicrobial resistance: a population perspective. Emerg Infect Dis. 8: 347-54.

Möller J, Luehmann T, Hall H, Vogel V. 2012. The race to the pole: how high-aspect ratio shape and heterogeneous environments limit phagocytosis of filamentous Escherichia coli bacteria by macrophages. Nano. Lett. 12: 2901-2905.

Möller J, Emge P, Avalos Vizcarra I, Kollmannsberger P, Vogel V. 2013. Bacterial filamentation accelerates colonization of adhesive spots embedded in biopassive surfaces. New J. Phys. 15: 1-19.

Pu Y, Zhao Z, Li Y, Zou J, Ma Q, Zhao Y, Ke Y, Zhu Y, Chen H, Baker MA, Ge H, Sun Y, Xie XS, Bai F. 2016. Enhanced Efflux Activity Facilitates Drug Tolerance in Dormant Bacterial Cells. Mol. Cell. 62: 284-294.

Sidhu PK, Landoni MF, Aliabadi FS, Lees P. 2010. PK-PD integration and modeling of marbofloxacin in sheep. Res Vet Sci. 88: 134-41.

Smith HJ, Nichol KA, Hoban DJ, Zhanel GG. 2003. Stretching the mutant prevention concentration (MPC) beyond its limits. J Antimicrob Chemother. 51: 1323-1325.

Theodore A, Lewis K, Vulic M. 2013. Tolerance of Escherichia coli to fluoroquinolone antibiotics depends on specific components of the SOS response pathway. Genetics 195: 1265-1276.

Wakamoto Y, Dhar N, Chait R, Schneider K, Signorino-Gelo F, Leibler S, McKinney JD. 2013. Dynamic persistence of antibiotic-stressed mycobacteria. Science 339: 91-95.

Wang JC. 2002. Cellular roles of DNA topoisomerases: a molecular perspective. Nat. Rev. Mol. Cell. Biol. 3: 430-440.

Young KD. 2006. The selective value of bacterial shape. Microbiol. Mol. Biol. Rev. 70: 660-703. 